\title{
Electrical Collection and Transmission Systems for Offshore Wind Power
}

Conference Paper NREL/CP-500-41135

March 2007

\section{Preprint}

J. Green, A. Bowen, L.J. Fingersh, and Y. Wan National Renewable Energy Laboratory

To be presented at the 2007 Offshore Technology Conference Houston, Texas

April 30 - May 3, 2007
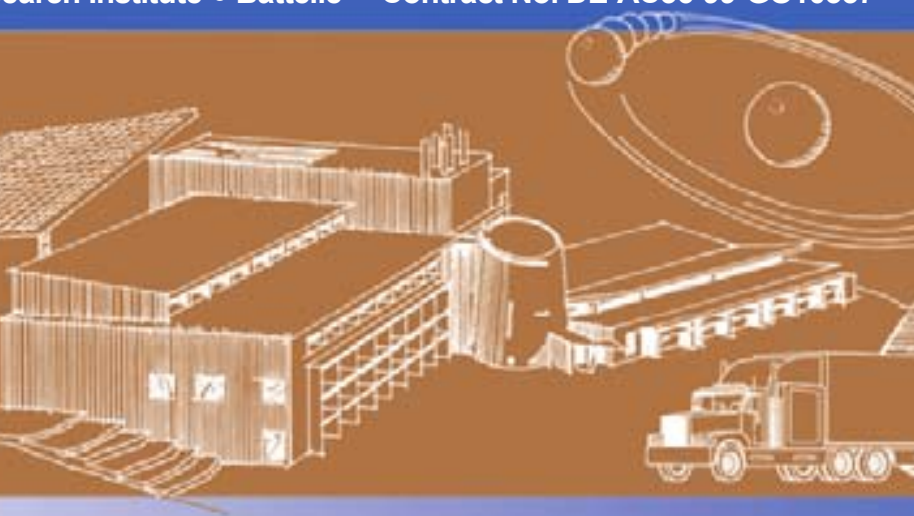


\section{NOTICE}

The submitted manuscript has been offered by an employee of the Midwest Research Institute (MRI), a contractor of the US Government under Contract No. DE-AC36-99G010337. Accordingly, the US Government and MRI retain a nonexclusive royalty-free license to publish or reproduce the published form of this contribution, or allow others to do so, for US Government purposes.

This report was prepared as an account of work sponsored by an agency of the United States government. Neither the United States government nor any agency thereof, nor any of their employees, makes any warranty, express or implied, or assumes any legal liability or responsibility for the accuracy, completeness, or usefulness of any information, apparatus, product, or process disclosed, or represents that its use would not infringe privately owned rights. Reference herein to any specific commercial product, process, or service by trade name, trademark, manufacturer, or otherwise does not necessarily constitute or imply its endorsement, recommendation, or favoring by the United States government or any agency thereof. The views and opinions of authors expressed herein do not necessarily state or reflect those of the United States government or any agency thereof.

Available electronically at http://www.osti.gov/bridge

Available for a processing fee to U.S. Department of Energy and its contractors, in paper, from:

U.S. Department of Energy

Office of Scientific and Technical Information

P.O. Box 62

Oak Ridge, TN 37831-0062

phone: 865.576 .8401

fax: 865.576 .5728

email: mailto:reports@adonis.osti.gov

Available for sale to the public, in paper, from:

U.S. Department of Commerce

National Technical Information Service

5285 Port Royal Road

Springfield, VA 22161

phone: 800.553 .6847

fax: 703.605.6900

email: orders@ntis.fedworld.gov

online ordering: http://www.ntis.gov/ordering.htm 


\title{
Electrical Collection and Transmission Systems for Offshore Wind Power
}

\author{
Jim Green, Amy Bowen, Lee Jay Fingersh, Yih-Huei Wan \\ National Renwable Energy Laboratory, Golden, Colorado
}

\begin{abstract}
The electrical systems needed for offshore wind farms to collect power from wind turbines - and transmit it to shorewill be a significant cost element of these systems. This paper describes the development of a simplified model of the cost and performance of such systems. The performance prediction accounts for losses as a function of the power produced in the wind farm and the length and size of the cables. The cost prediction is flexibly formulated so wind farm configurations can be evaluated by parameters such as the number of wind turbines, wind turbine size, turbine array configuration and spacing, and distance from shore. The collection system - the medium-voltage electrical grid within the wind farm, and the transmission system - the high-voltage electrical connection to an on-shore transmission line - are treated independently in the model. Data sources for the model and limitations of the data are discussed, and comparison is made to costs reported by others. The choice of transmission system technology is also addressed. This electrical system model is intended for integration into a more comprehensive model of offshore wind farm design, cost, and performance that will be used for parametric studies and optimization of wind farm configurations. Because some concepts for future offshore wind installations in deep water use floating platforms, this paper briefly discusses the application of submarine cable technology to nonfixed termination points, a departure from current practice.
\end{abstract}

\section{Introduction}

The National Wind Technology Center (NWTC) of the National Renewable Energy Laboratory (NREL) in Golden, Colorado, has undertaken a series of concept studies to evaluate the cost and performance of offshore wind farms. The product of these studies will be a comprehensive model of offshore wind farm design, cost, and performance suitable for parametric studies and optimization of wind farm configurations. The overall goal of this effort is to help identify technology pathways for offshore wind energy development and deployment in the United States. Offshore wind farms present an attractive option because they allow for larger wind turbines that operate in higher wind resources than land-based [1,2]. Offshore installations are also more expensive, so an understanding of their performance, cost, and optimal configurations is needed.
This paper is an overview of one of these concept studies. It focuses on the power losses in wind farm electrical power collection and transmission systems, as well as the costs of the system components and their installation. A hypothetical system was based loosely on the Horns Rev offshore wind farm in Denmark. Inquiries were made with manufacturers about electrical and cost data on the required components, which were then compiled in a spreadsheet model. The performance prediction accounts for losses as a function of power output of the wind farm and length and size of the cables. The cost prediction is flexibly formulated so wind farm configurations can be evaluated by parameters such as the number of wind turbines, wind turbine size, turbine array configuration and spacing, and distance from shore.

\section{Electrical System Overview}

The electrical system for an offshore wind farm consists of a medium-voltage electrical collection grid within the wind farm and a high-voltage electrical transmission system to deliver the power to an onshore transmission line.

\section{Collection System}

The collection grid begins with transformers at each wind turbine, usually in the base of the tower, to step up from the generation voltage, typically 690 volts (V), to a medium voltage of typically $25-40$ kilovolts $(\mathrm{kV})$. This voltage range seems to be preferred because standardized equipment is available at competitive prices and because higher voltage transformers would be too big to fit readily into the tower cross sections. A grid of medium-voltage submarine cables, typically buried 1-2 meters (m) deep in the seabed, is used to connect the wind turbines to an offshore substation.

\section{Transmission System}

The transmission system begins at the offshore substation, which steps up the voltage to a transmission voltage of 130$150 \mathrm{kV}$, the highest voltages in use today for AC submarine cables. This higher voltage allows a much smaller diameter and lower cost submarine cables to be used for the long run to shore. Only three offshore wind farms in operation today have offshore substations. However, these stations are expected to be the least-cost option for wind farms that will be larger and further offshore than current practice. Such wind farms are the main target of this inquiry. 
From the offshore substation, a high-voltage submarine cable (which is also buried in the seabed for protection) carries the power to shore. Once it makes landfall, the run continues, either underground or overhead, to an onshore substation for connection to a transmission line. An additional transformer may be used in this substation to step up the voltage to a higher level to match the transmission grid.

Two technology options are available for the transmission system: high-voltage AC (HVAC) and high-voltage DC (HVDC). The current consensus is that HVAC is the most economical option for distances shorter than 50 kilometers $(\mathrm{km})[2,3,4]$. This technology is assumed for our model. Between 50 and $80 \mathrm{~km}, \mathrm{HVAC}$ and HVDC are expected to be similar in cost. Longer than $80 \mathrm{~km}$, HVDC systems will likely be least cost, mainly because the capacity of a given HVAC cable drops off with distance due to the capacitive and inductive characteristics of the cable and their associated losses. DC transmission avoids these losses entirely, so it is the preferred technology for longer distances.

\section{Obtaining Cost and Performance Data}

Our study began by examining European offshore wind farms. One of the best documented is Horns Rev, a 160-megawatt (MW) farm that began operation off the coast of Denmark in 2002 [5]. Horns Rev is also one of the two largest offshore wind farms in operation and was the first to use an offshore substation. The collection and transmission cables are rated at $36 \mathrm{kV}$ and $150 \mathrm{kV}$, respectively with XLPE (cross-linked polyethylene) insulation. We used these parameters to create a model of an example wind farm rated at $500 \mathrm{MW}$. Requests for high-voltage submarine power cable cost and performance were sent to five manufacturers. Three responded to our requests with preliminary engineering estimates. These estimates were converted to a value in U.S. \$/m and loss, kilowatts $(\mathrm{kW}) / \mathrm{m}$, for application in our model. Similar methods were used to determine the shipping and installation costs for the cable.

Submarine power cables are custom manufactured to meet the requirements of each unique project; as a result, extensive electrical and cost data on specific cable sizes and types are not readily available. We found that performance and cost data are highly variable between manufacturers. In fact, one manufacturer provided cable prices about twice as high as the other two. We have concluded those prices are not representative of the market and we are not reporting them here. During interviews with manufacturers, we determined that this variability could arise for numerous reasons: high demand for cable from a particular company, rapid inflation in commodity prices, company policy to bid conservatively (especially when little is known about the application), the customized nature of cable design, and setup and tooling costs that are unique to each design.

Two manufacturers provided performance data for their cables. In addition to an inconsistency in these variables, we had too little information about the cables themselves to calculate losses from first principles. However, both data sets contained values for current rating or ampacity (amperes), $\mathrm{I}_{\text {rated }}$, and power losses $(\mathrm{kW})$ at full capacity, $\mathrm{P}_{\mathrm{c}}$. We developed a method for calculating power losses that relies on $\mathrm{I}_{\text {rated }}, \mathrm{P}_{\mathrm{c}}$, and the resistance of the copper conductor, $\mathrm{R}$ (ohms).

Although $\mathrm{R}$ was listed on only one data sheet, resistances are readily calculated for copper conductors of known size. The total losses were divided into two parts: losses $(\mathrm{kW})$ that vary with current, which were modeled as a quadratic term, $\mathrm{P}_{\mathrm{i}}$; and a base loss $(\mathrm{kW}), \mathrm{P}_{\mathrm{b}}$, that does not vary with current, modeled as a constant. $\mathrm{P}_{\mathrm{i}}$ and $\mathrm{P}_{\mathrm{b}}$ are calculated as follows:

$$
\begin{aligned}
& P_{i}=I_{\text {rated }}{ }^{2} \times R \\
& P_{b}=P_{c}-P_{i}
\end{aligned}
$$

A transformer manufacturer was contacted to request cost and performance data for three transformer applications. These transformers contain a special type of liquid coolant that is biodegradable, nontoxic, and suitable for offshore use [6]. Transformer specifications were developed based on the system voltages and power levels throughout the collection and transmission systems. For installation in each wind turbine tower, we priced a 3.16-mega-volt-amperes (MVA) transformer to step up the voltage from an assumed 3-MW wind turbine's $690-\mathrm{V}$ generation voltage to the collection system's $34 \mathrm{kV}$. The offshore substation contains three, 187MVA transformers that step up the voltage from $34 \mathrm{kV}$ to the transmission system voltage of $138 \mathrm{kV}$. (We selected operating voltages that are slightly lower than the cable voltage ratings.) Lastly, a single 560-MVA transformer is located at an onshore substation to step up to an assumed onshore transmission system voltage of $345 \mathrm{kV}$. This voltage level is typical of a transmission system that can receive 500 MW of generation.

\section{Results}

\section{Unit Costs and Performance}

Table 1 is a cost summary (in $\$ / \mathrm{m}$ ) for submarine cables from two companies. All cables are AC, contain a single layer of steel armor, and are XLPE insulated. Table 2 is a cost summary for the transformers for the tower base, the offshore substation, and the onshore substation. 
Table 1. Costs for cables with specific conductor sizes from two companies. Highlighted costs were extrapolated from known costs.

\begin{tabular}{|c|c|c|}
\hline \multirow{2}{*}{$\begin{array}{c}\text { Conductor } \\
\text { Size } \mathbf{~ m m}^{2}\end{array}$} & Company A & Company B \\
\cline { 2 - 3 } & Cost $\mathbf{( \$ \mathbf { m } )}$ & Cost $\mathbf{( \$ \mathbf { m } )}$ \\
\hline \multicolumn{3}{|c|}{ Collection System } \\
\hline $\mathbf{9 5}$ & 152 & 455 \\
\hline $\mathbf{1 5 0}$ & 228 & 494 \\
\hline $\mathbf{4 0 0}$ & 381 & 609 \\
\hline $\mathbf{6 3 0}$ & 571 & 635 \\
\hline $\mathbf{8 0 0}$ & 600 & 731 \\
\hline \multicolumn{3}{|c|}{ Transmission System } \\
\hline $\mathbf{6 3 0}$ & 755 & 860 \\
\hline
\end{tabular}

Table 2. Transformer unit costs.

\begin{tabular}{|c|c|c|}
\hline Location & $\begin{array}{c}\text { Voltage \& } \\
\text { Capacity }\end{array}$ & Unit Cost \\
\hline Wind Turbine & $\begin{array}{c}690 / 34 \mathrm{kV} \\
3.16 \mathrm{MVA}\end{array}$ & $\$ 50,500$ \\
\hline Offshore & $34 / 138 \mathrm{kV}$ & \\
Substation & $187 \mathrm{MVA}$ & $\$ 2,618,000$ \\
\hline Onshore & $138 / 345 \mathrm{kV}$ & \\
Substation & $560 \mathrm{MVA}$ & $\$ 5,600,000$ \\
\hline
\end{tabular}

Figures 1 and 2 show performance data for submarine cables from two companies. The power losses in Figures 1 and 2 are computed at steps that correspond to $3 \mathrm{MW}$ of additional power in a $34-\mathrm{kV}$ line. As the power level increases, the current on the line and thus the power loss increases. Electrical data were not available for the transmission system cables, so no power loss estimation for high voltage operation is provided here. The actual losses for an operating wind farm, which are a function of power level (and in turn a function of wind speed), will be applied in the final wind farm model.

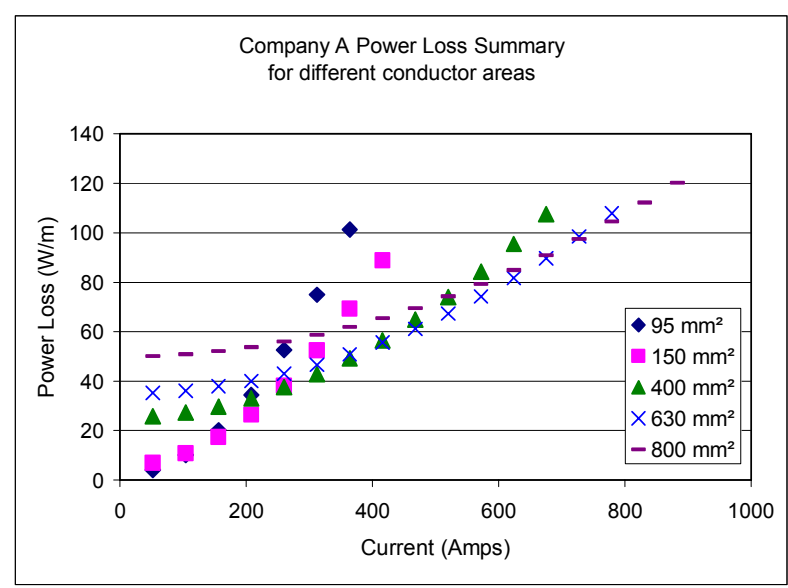

Figure 1. Loss results for Company A cables at various currents for several conductor sizes.

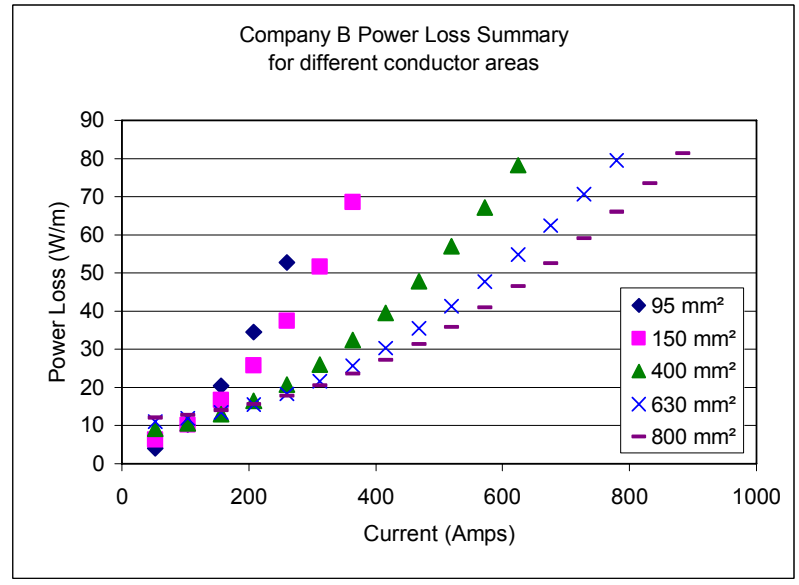

Figure 2. Loss results for Company B cables at various currents for several conductor sizes.

We also contacted a domestic submarine cable installer who provided us with a preliminary engineering estimate for cable shipping and installation, which we then converted to a base value and a $\$ / \mathrm{m}$ value to allow for variability in cable length (see Table 3). Mobilization, demobilization, marine route survey, and route engineering costs are given as fixed costs; shipping and cable laying costs vary with cable length.

Table 3. Installation cost breakdown.

\begin{tabular}{|l|c|c|}
\hline & East Coast & West Coast \\
\hline $\begin{array}{l}\text { Marine Route Survey } \\
\text { \& Engineering }\end{array}$ & $\$ 1,500 \mathrm{~K}$ & $\$ 2,000 \mathrm{~K}$ \\
\hline $\begin{array}{l}\text { Cable Transport } \\
\text { Via Freighter from } \\
\text { Europe }(\$ / \mathrm{m})\end{array}$ & $\$ 58$ & $\$ 85$ \\
\hline $\begin{array}{l}\text { Mobilization/ } \\
\text { Demobilization }\end{array}$ & $\$ 5,000 \mathrm{~K}$ & $\$ 6,000 \mathrm{~K}$ \\
\hline $\begin{array}{l}\text { Cable Laying } \\
\text { Operations }(\$ / \mathrm{m})\end{array}$ & $\$ 94$ & $\$ 103$ \\
\hline
\end{tabular}

Cost for an offshore substation for a 240-MW farm was obtained from the SeaWind concept study [7]. We adjusted this number to account for the difference in size, foreign excahange rates, and inflation resulting in a value of $\$ 40.52$ million (2006 \$) for a $500 \mathrm{MW}$ offshore substation.

\section{MW Wind Farm}

After we compiled the unit cost data in the spreadsheet, we considered alternative layouts for an example $500 \mathrm{MW}$ wind farm to assess impacts on wind farm power losses and costs. All collection grid layouts investigated were radial from the offshore substation. The numbers of rows and number of turbines per row were varied for different layouts; see Figure 3 for a 21-row layout with eight turbines per row. 


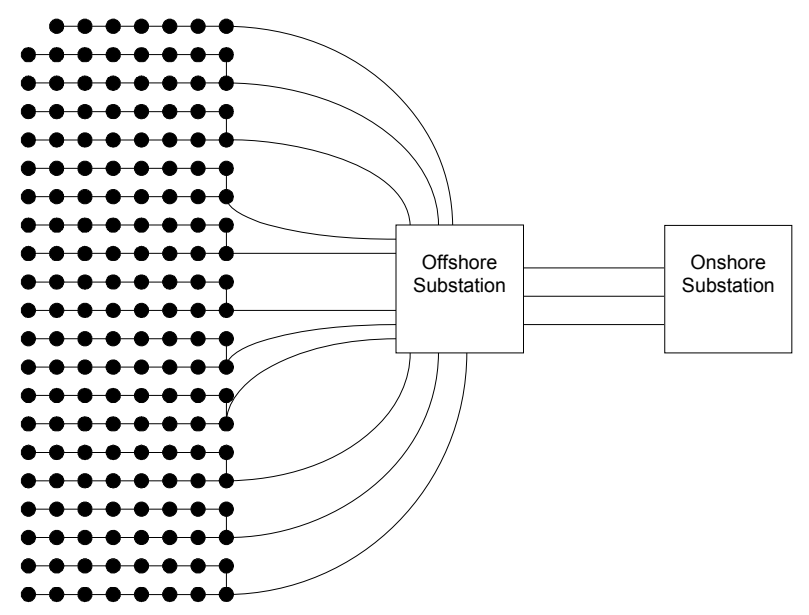

Figure 3. $500 \mathrm{MW}$ wind farm layout with $3 \mathrm{MW}$ qind turbines. Diagram not drawn to scale.

Table 4 summarizes the input parameters of this example wind farm. The 630 meter distance between rows and between turbines is 7 times the rotor diameter of 90 meters. A cable length between turbines of 830 meters allows ample room for installation and topographical differences in the ocean floor. The cables connecting the collection grid to the offshore substation vary in length based on their location but are each approximately 7 kilometers. The number of transformers and their costs for this $500 \mathrm{MW}$ system are shown in Table 5.

Table 4. $500 \mathrm{MW}$ wind farm parameters

\begin{tabular}{|l|l|}
\hline Wind turbine rating & $3 \mathrm{MW}$ \\
\hline Number of wind turbines & 167 \\
\hline Rotor diameter & $90 \mathrm{~m}$ \\
\hline Water depth & $20 \mathrm{~m}$ \\
\hline Distance between turbines & $630 \mathrm{~m}$ \\
\hline Distance between rows & $630 \mathrm{~m}$ \\
\hline $\begin{array}{l}\text { Cable length between turbines \& } \\
\text { between rows }\end{array}$ & $830 \mathrm{~m}$ \\
\hline Substation distance to shore & $15 \mathrm{~km}$ \\
\hline Length of onshore transmission & $15 \mathrm{~km}$ \\
\hline
\end{tabular}

Table 5. Transformer cost summary for $500 \mathrm{MW}$ wind farm.

\begin{tabular}{|c|c|c|c|}
\hline Location & Quantity & Unit Cost & Total Cost \\
\hline Wind Turbines & 167 & $\$ 50,500$ & $\$ 8,433,500$ \\
\hline $\begin{array}{c}\text { Offshore } \\
\text { Substation }\end{array}$ & 3 & $\$ 2,618,000$ & $\$ 7,854,000$ \\
\hline $\begin{array}{c}\text { Onshore } \\
\text { Substation }\end{array}$ & 1 & $\$ 5,600,000$ & $\$ 5,600,000$ \\
\hline
\end{tabular}

Table 6 is a summary of total wind farm costs and losses for Companies A and B. Cable cost, cable shipping and installation, tower transformers, offshore transformer substation, and onshore transmission and substation are included in these costs. Power losses are computed at the wind farm's rated power and, thus, are not representative of actual operating losses. (Transmission losses are based on extrapolations of losses at medium voltage and should be considered rough estimates.)

Table 6. Cost and performance summary for a $500 \mathrm{MW}$ offshore wind farm. All costs are in millions $\$$ and all power losses are in MW at rated power.

\begin{tabular}{|c|c|c|c|}
\hline & Layout 1 & Layout 2 & Layout 3 \\
\hline Turbines per row & 8 & 7 & 6 \\
\hline \# of Rows & 20.9 & 23.9 & 27.9 \\
\hline \begin{tabular}{|l} 
Turbine \\
Transformer Cost
\end{tabular} & $\$ 8.43$ & $\$ 8.43$ & $\$ 8.43$ \\
\hline $\begin{array}{l}\text { Collection Cable } \\
\text { Shipping \& Install Cost }\end{array}$ & $\$ 36.53$ & $\$ 38.36$ & $\$ 42.84$ \\
\hline $\begin{array}{l}\text { Transmission Cable } \\
\text { Shipping \& Install Cost }\end{array}$ & $\$ 6.83$ & $\$ 6.83$ & $\$ 6.83$ \\
\hline $\begin{array}{l}\text { Offshore Substation } \\
\text { w/Transformers }\end{array}$ & $\$ 40.52$ & $\$ 40.52$ & $\$ 40.52$ \\
\hline $\begin{array}{l}\text { Onshore Transmission } \\
\& \text { Substation }\end{array}$ & $\$ 29.37$ & $\$ 29.37$ & $\$ 29.37$ \\
\hline \multicolumn{4}{|c|}{ Company A } \\
\hline $\begin{array}{l}\text { Collection } \\
\text { Cable Cost }\end{array}$ & $\$ 82.85$ & $\$ 86.64$ & $\$ 78.78$ \\
\hline $\begin{array}{l}\text { Transmission } \\
\text { Cable Cost }\end{array}$ & $\$ 33.98$ & $\$ 33.98$ & $\$ 33.98$ \\
\hline $\begin{array}{l}\text { Collection } \\
\text { Losses (MW) }\end{array}$ & 11.96 & 11.86 & 14.21 \\
\hline $\begin{array}{l}\text { Transmission } \\
\text { Losses (MW) }\end{array}$ & 2.88 & 2.88 & 2.88 \\
\hline $\begin{array}{l}\text { Total Cost and } \\
\text { Unit Cost }\end{array}$ & $\begin{array}{l}\$ 238.57 \\
\$ 477 / \mathrm{kW} \\
\end{array}$ & $\begin{array}{l}\$ 244.13 \\
\$ 488 / \mathrm{kW} \\
\end{array}$ & $\begin{array}{l}\$ 240.75 \\
\$ 482 / \mathrm{kW} \\
\end{array}$ \\
\hline Total Losses (MW) & 14.84 & 14.74 & 17.09 \\
\hline \multicolumn{4}{|c|}{ Company B } \\
\hline $\begin{array}{l}\text { Collection } \\
\text { Cable Cost } \\
\end{array}$ & $\$ 123.15$ & $\$ 122.54$ & $\$ 136.88$ \\
\hline $\begin{array}{l}\text { Transmission } \\
\text { Cable Cost }\end{array}$ & $\$ 38.70$ & $\$ 38.70$ & $\$ 38.70$ \\
\hline $\begin{array}{l}\text { Collection } \\
\text { Losses (MW) }\end{array}$ & 7.81 & 8.29 & 11.27 \\
\hline $\begin{array}{l}\text { Transmission } \\
\text { Losses (MW) }\end{array}$ & 2.88 & 2.88 & 2.88 \\
\hline $\begin{array}{l}\text { Total Cost and } \\
\text { Unit Cost }\end{array}$ & $\begin{array}{l}\$ 283.53 \\
\$ 567 / \mathrm{kW} \\
\end{array}$ & $\begin{array}{l}\$ 284.75 \\
\$ 570 / \mathrm{kW} \\
\end{array}$ & $\begin{array}{l}\$ 303.57 \\
\$ 607 / \mathrm{kW} \\
\end{array}$ \\
\hline Total Losses (MW) & 10.69 & 11.17 & 14.15 \\
\hline
\end{tabular}

\section{Cost Comparison to Other Sources}

The cost data used in this study were compared to the cost data reported by Neilson [7] and Gerdes et al. [8]. When a direct match could not be made between the cables used in these studies, the cable with the dimensions closest to those specified was used. The data was corrected for inflation and foreign exchange rates and are reported here as 2006 costs.

For this comparison, we did not create wind farm array configurations. We simply calculated total cost by multiplying the length of the cable from the Seawind study [7] by the $\$ / \mathrm{m}$ data from both of the manufactures in our study. Table 7 shows the individual cable costs and the total cost results for both Seawind and our study. 
Table 7. Comparison to Seawind cable costs.

\begin{tabular}{|c|c|c|c|c|}
\hline $\begin{array}{l}\text { Length } \\
\text { (m) }\end{array}$ & $\begin{array}{c}\text { Voltage } \\
\text { (kV) }\end{array}$ & $\begin{array}{c}\text { Area } \\
\left(\mathrm{mm}^{2}\right)\end{array}$ & $\begin{array}{l}\text { Cost } \\
\$ / \mathrm{m}\end{array}$ & $\begin{array}{l}\text { Total } \\
\text { (\$M) }\end{array}$ \\
\hline \multicolumn{5}{|c|}{ Seawind } \\
\hline 35,500 & 150 & 630 & 641 & 22.76 \\
\hline \multirow[t]{2}{*}{39,714} & 30 & 300 & 128 & 5.08 \\
\hline & & & & 27.84 \\
\hline \multicolumn{5}{|c|}{ Company A } \\
\hline 35,500 & 170 & 630 & 755 & 26.80 \\
\hline \multirow[t]{2}{*}{39,714} & 36 & 400 & 381 & 15.33 \\
\hline & & & & 42.13 \\
\hline \multicolumn{5}{|c|}{ Company B } \\
\hline 35,500 & 150 & 630 & 860 & 30.53 \\
\hline \multirow{2}{*}{39,714} & 36 & 400 & 609 & 24.18 \\
\hline & & & & 54.71 \\
\hline
\end{tabular}

All our cable costs are higher than those in the Seawind report. The price of copper increased significantly between 2003 (when the Seawind study was performed) and the summer of 2006 (when our data were collected), at one time by more than $300 \%$. This increase may partially explain the differences between the costs in these two studies. A manufacturer reported that commodity prices are about one-third of the cable cost. Changing foreign exchange rates may also have been a factor

In addition, the results from our loss calculation method were compared to the results obtained by the Seawind study. The Seawind study provided the losses at full load for different wind farm sizes with a $300 \mathrm{~mm}^{2}$ conductor cable at $30 \mathrm{kV}$. Table 8 show these losses for Seawind and the full load losses based on our data for a $400 \mathrm{~mm}^{2}$ conductor cable at $36 \mathrm{kVa}$. There is a reasonable match between these data sets, although lower losses might have been expected from our data given the larger cable size and higher assumed operating voltage.

Table 8. Comparison to Seawind full load losses.

\begin{tabular}{cccc}
$\begin{array}{c}\text { Size } \\
\text { (MW) }\end{array}$ & $\begin{array}{c}\text { Seawind } \\
\text { (\% lost) }\end{array}$ & $\begin{array}{c}\text { Company A } \\
\text { (\% lost) }\end{array}$ & $\begin{array}{c}\text { Company B } \\
\text { (\% lost) }\end{array}$ \\
\hline 15 & 0.603 & 1.253 & 0.690 \\
30 & 1.203 & 1.234 & 0.950
\end{tabular}

Table 9 shows a comparison of the actual transmission system costs for Horns Rev [8] and the predicted costs from our study. Note: the dimensions of the onshore cables differ between Horns Rev and our data. Our costs compare reasonably well with Horns Rev.
Table 9. Comparison of transmission cable and substation costs to the actual cost for Horns Rev.

\begin{tabular}{lccc} 
& & \multicolumn{2}{c}{ Company } \\
\hline & Actual & A & B \\
\hline Onshore Cables & & 10.55 & 10.55 \\
\hline Offshore Cables & & 15.86 & 18.06 \\
\hline $\begin{array}{l}\text { Offshore Substation } \\
\text { w/Transformers }\end{array}$ & & 12.87 & 12.87 \\
\hline Total $(\$ M)$ & 39.45 & 39.28 & 41.48
\end{tabular}

Table 10 shows a similar comparison between the actual costs of the Nysted transmission system and our cost estimate. Note: the dimensions of the cables differ between Nysted and our study. Once again, the cost comparison is reasonably good.

Table 10. Comparison of transmission cable and substation costs to the actual costs at Nysted.

\begin{tabular}{lccc} 
& & \multicolumn{2}{c}{ Company } \\
\hline & Actual & A & B \\
\hline $\begin{array}{l}\text { Onshore Substation \& } \\
\text { Transformer }\end{array}$ & & 8.4 & 8.4 \\
\hline Onshore Cables & 5.59 & 5.59 \\
\hline Offshore Cables & 8.31 & 9.46 \\
\hline $\begin{array}{l}\text { Offshore Substation } \\
\text { w/Transformers }\end{array}$ & & 13.32 & 13.32 \\
\hline Total $(\$ M)$ & 37.80 & 35.62 & 36.77
\end{tabular}

\section{Reducing Cable Cost}

Several options for reducing electrical system cost emerged in the course of our study. These options may be technically feasible, but each comes with some added risk of reduced reliability. Because submarine cables require significant capital investments and are relatively inaccessible for maintenance, buyers are conservative with a strong preference for designs with proven records.

1. Don't bury the collection system cables in the seabed between wind turbines, since the risk of damage within the wind farm from boat anchors, commercial fishing, etc., is low compared to the more exposed transmission cable to shore. Laying cable on the seabed costs less than buried cable installation.

2. For copper conductors, the lead sheath is not strictly necessary. A copper wire sheath can be used instead to provide an effective electrical shield. Lead sheathing is commonly specified as a conservative approach that provides one more seawater barrier for the conductors. Lead sheathing is more expensive because it uses a larger volume of material applied in an extrusion process.

3. Alternatively, aluminum conductors can be used in place of copper can reduce both cost and weight. Conductor cost alone could be lower by about a factor of 6 (at 2006 commodity prices), and cable costs might be reduced $15 \%-20 \%$. Seawater exposure of aluminum results in corrosion and off-gassing, so using a lead shield for maximum seawater isolation will be prudent. 
4. Power cables for wind farms should be designed with cable thermal mass in mind. One manufacturer noted that a buried cable/soil system has a thermal time constant of about one week. Typically, wind farms are not at peak power continuously. Intermittency of the wind resource may allow cable thermal design to be based on current level less than that at peak wind farm output. Temperature monitoring of cables is feasible with fiber optics, though the optical fibers are reported to be less robust than the cables.

5. One cable manufacturer recommended that performancebased cable specifications be used instead of design-based specifications to give the manufacturers greater flexibility to use their knowledge and experience to explore costeffective designs.

\section{Cables for Floating Platforms}

Some concepts for future offshore wind installations in deep water use floating platforms [1], which will not provide static termination points for submarine power cables. These cables will be subjected to some finite motion: heave, sway, torsion, or some combination of the three. Clearly the medium- and high-voltage submarine cable designs in use today will not be adequate for this service, primarily because the lead sheathing around the electrical conductors has very poor fatigue properties. This issue has not been addressed by the oil and gas industry because the risers typically used for floating oil and gas platforms are communications cables and pipelines for oil and gas, not high-voltage power cables. These platforms typically operate with $13.8-\mathrm{V}$ power, not the higher voltages needed for offshore wind.

One option might be to switch from lead to copper sheathing around the electrical conductor. Removing the lead creates a much more fatigue-resistant cable. Of course, the fatigue properties of cables without lead sheathing will need to be determined and evaluated in light of the dynamic characteristics of particular floating platform designs. However, a copper sheath, typically a mesh of copper wires, which provides necessary electrical shielding, is not a seawater barrier as is a continuous lead sheath. Thus long-term resistance of the cable to seawater intrusion will be reduced. Other issues will include means to distribute cable bending, i.e. to limit bending radius; creating resistance to cable abrasion against the seabed; and finding suitable means to support cable weight if the cable must be used in a droop configuration. In contrast, experience with submarine cables is limited to stationary and fully supported installations, typically laid on or trenched into the seabed. Care is taken to protect cables from seabed scouring, in particular at the bottom of wind turbine towers, which could leave a length of cable suspended above the bottom and vulnerable to movement.

\section{Conclusion}

The NREL NWTC in Golden, Colorado, has undertaken a series of concept studies to evaluate the cost and performance of offshore wind farms. This paper reports on one of these concept studies that focused on the costs and losses in wind farm electrical power collection and transmission systems.
We believe the cost and performance data reported here are well suited for parametric studies of wind farm size and configuration. However, we recommend some caution about the use of these data for estimating absolute costs.

Uncertainties in absolute cost arise from factors such as changing commodity prices, changing foreign exchange rates, changing levels of demand for goods and service in this industry, and the impact of project-specific design parameters. Also, losses in submarine cables appear to depend on the specific cable design and, perhaps, the manufacturer.

Submarine power cables are highly customized for each application, so generalizations about cost and performance are estimates at best.

This study was limited to electrical system componentssubmarine cables, the offshore substation, and transformersthat contribute the most to system cost. Devices we have not addressed, including switches, circuit protection, and compensation devices, have much lower costs, but are nonetheless important to wind farm operation. Our cost model can be improved with further research of the cost and performance of these devices. Our model also needs data about losses in high-voltage transmission cables, which were not available from manufacturers during our study.

Our studies illustrate how wind farm layout affects collection system cable losses and cost. Changes in cable size will move cable cost and performance in opposite directions. These tradeoffs between configuration, cost, and performance point to the importance of performing parametric studies of the entire system to seek optimum configurations. The comparisons we made of our transmission system cost data to published data for wind farms showed that our costs matched very well.

One critical research need for offshore wind farm electrical systems is technology for nonstatic power cable terminations. Submarine power cable technology is vulnerable to fatigue failures. Fatigue-resistant cable technology must be developed if floating platforms are to be used for offshore wind farms in deep water.

\section{Acknowledgments}

This work was funded by the U.S. Department of Energy (DOE) Wind Technology Program. The DOE Office of Science funded the Student Undergraduate Laboratory Intern program that brought Ms. Bowen onto our team. The authors wish to acknowledge the support of our colleagues at the NWTC, Walt Musial, Maureen Hand, and Alan Laxson, for helping us to formulate and scope this study. Roger Rosenquvist, Ove Tollerz, and Bo Martinsson of ABB were particularly helpful in providing information as to the cost of and technologies used in submarine power cables. We are grateful to Neil Giles of Nexans and Safiq Virani of Fujikura for providing budgetary cost estimates for cables. Bill Wall of Caldwell Marine International was particularly helpful on the logistics of submarine cable installation. 


\section{References}

[1] W. Musial et al. "Energy from Offshore Wind. 2006 Offshore Technology Conference, Houston, Texas. May 2006. NREL Report No. CP-500-39450.

[2] T. Ackermann, "Transmission Systems for Offshore Wind Farms," Wind Power in Power Systems, Ed. T.

Ackermann, West Sussex, England: John Wiley \& Sons, Ltd., 2005, pp. 479 - 503.

[3] T. Ackermann, "Technical/Economic Feasibility Of Different Technologies for Transmission System Between Offshore Wind Farm and the Shore," September, 2006. DOWNVInD Project, Deliverable no. 1-4.

[4] S. D. Wright, A.L. Rogers, J. F. Manwell, and A. Ellis, "Transmission Options for Offshore Wind Farms in the United States," in Proceedings of the AWEA Annual Conference, 2002, pp. $1-12$.

[5] Horns Rev Offshore Wind Farm Homepage, July 2006, http://www.hornsrev.dk/Engelsk/default_ie.htm

[6] P. McShane, "Vegetable-Oil-Based Dielectric Coolants," IEEE Industry Applications Magazine, vol. 8, no. 3, pp. 34-41, May-June 2002.

[7] P. Nielson, "Offshore Wind Energy Projects Feasibility Study Guidelines," [Online document], 2003 June (Ver 3.0), [cited 2006 Aug 07], http://www.emd.dk/Projects/ Projekter/Seawind/OTHER\%20RELEVANT\%20DOCOP PERMENTS/Feasibility\%20Study\%20Guidelines.pdf

[8] G. Gerdes, et al. Case Study: European Offshore Wind Farms - A Survey for the Analysis of the Experiences and Lessons Learnt by Developers of Offshore Wind Farms Final Report. Published by the EU project "POWER Pushing Offshore Windfarm Regions." No date given. 


\section{REPORT DOCUMENTATION PAGE}

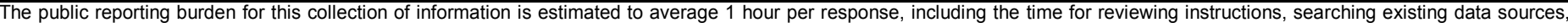

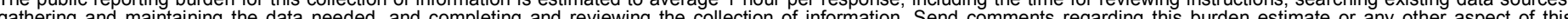

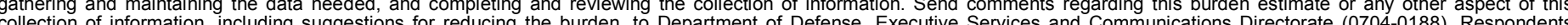

should be aware that notwithstanding any other provision of law, no person shall be subject to any penalty for faling the

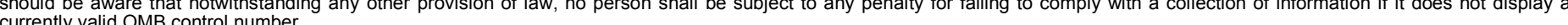

PLEASE DO NOT RETURN YOUR FORM TO THE ABOVE ORGANIZATION.

\section{REPORT DATE (DD-MM-YYYY) \\ March 2007 \\ 2. REPORT TYPE \\ Conference paper}

4. TITLE AND SUBTITLE

Electrical Collection and Transmission Systems for Offshore Wind

Power: Preprint
3. DATES COVERED (From - To) April 30 - May 3, 2007

5a. CONTRACT NUMBER

DE-AC36-99-G010337

5b. GRANT NUMBER

5c. PROGRAM ELEMENT NUMBER

5d. PROJECT NUMBER

NREL/CP-500-41135

5e. TASK NUMBER

WER7.6001

5f. WORK UNIT NUMBER
7. PERFORMING ORGANIZATION NAME(S) AND ADDRESS(ES)

National Renewable Energy Laboratory

1617 Cole Blvd.

Golden, CO 80401-3393
8. PERFORMING ORGANIZATION REPORT NUMBER

NREL/CP-500-41135

9. SPONSORING/MONITORING AGENCY NAME(S) AND ADDRESS(ES)

10. SPONSOR/MONITOR'S ACRONYM(S) NREL

11. SPONSORING/MONITORING AGENCY REPORT NUMBER

12. DISTRIBUTION AVAILABILITY STATEMENT

National Technical Information Service

U.S. Department of Commerce

5285 Port Royal Road

Springfield, VA 22161

13. SUPPLEMENTARY NOTES

14. ABSTRACT (Maximum 200 Words)

The electrical systems needed for offshore wind farms to collect power from wind turbines-and transmit it to shorewill be a significant cost element of these systems. This paper describes the development of a simplified model of the cost and performance of such systems.

\section{SUBJECT TERMS}

wind energy; wind turbines; transmission systems; wind electrical systems; offshore wind development

\begin{tabular}{l}
\hline \begin{tabular}{l|l|l|}
\hline 16. SECURITY CLASSIFICATION OF: \\
\hline $\begin{array}{l}\text { a. REPORT } \\
\text { Unclassified }\end{array}$ & $\begin{array}{c}\text { b. ABSTRACT } \\
\text { Unclassified }\end{array}$ & $\begin{array}{l}\text { c. THIS PAGE } \\
\text { Unclassified }\end{array}$ \\
& & \\
\hline
\end{tabular}
\end{tabular}

\begin{tabular}{|c|c|}
\hline $\begin{array}{l}\text { 17. LIMITATION } \\
\text { OF ABSTRACT }\end{array}$ & $\begin{array}{l}\text { 18. NUMBER } \\
\text { OF PAGES }\end{array}$ \\
\hline UL & \\
\hline
\end{tabular}

19a. NAME OF RESPONSIBLE PERSON

19b. TELEPHONE NUMBER (Include area code) 